\title{
Public Private Partnerships for Transportation Infrastructure Delivery
}

\author{
Francesca Leccis \\ Department of Civil Engineering, Environmental Engineering and Architecture, University of Cagliari, \\ Cagliari, Italy \\ Email: francescaleccis@unica.it
}

Received 11 February 2015

\begin{abstract}
The term Public Private Partnerships includes different forms of collaboration between the public and the private sector. These formulas are adopted in a constantly increasing number of countries all over the world in order to overcome the chronic lack of funding and ensure the delivery of infrastructure projects. The paper illustrates the vital role of cooperation between public bodies and private entities in the delivery of public transportation infrastructure. In particular, it focuses on toll roads and highways. Key factors of success and risk are identified and illustrated through five case studies from Chile, Hungary, South Africa-Mozambique, United Kingdom and California.
\end{abstract}

\section{Keywords}

Public-Private Partnerships, Infrastructure, Transport, Highways, Toll Roads, Tolls

\section{Introduction}

This paper illustrates the vital role of cooperation between public bodies and private entities in the delivery of public transportation infrastructure. In particular, it focuses on toll roads and high-ways. First of all, reasons for the choice are stated and aim and methodology are described. Subsequently, the various forms of Public Private Partnership are classified. Afterwards, key factors of success and major risks are identified and illustrated through five case studies from Chile, Hungary, South Africa-Mozambique, United Kingdom and California. Finally, useful conclusions for good practice are drawn.

\section{Choice, Aim and Methodology}

The choice of the topic is strictly related to the relevance of the collaboration between the public and private sectors in the current strategies for economic recovery from the crisis caused by the Property Bubble Crash in 2008. Indeed, infrastructure investments are considered a fundamental tool to overcome this crisis and to support a sustainable economic growth [1]. The study conducted by Canning and Fay [2] sustains this view by demonstrating that investments in infrastructure increase the growth of productivity. Similarly, Milbourne et al. [3] underlined a positive impact of public investment in transportation in the economic growth. However, due to the chronic budgetary problems, many countries look for financial help in the private sector by establishing different 
kinds of cooperation [4].

The aim of the paper is to contribute to the enhancement of collaboration agreements between the public and private sectors. In order to achieve this, the paper illustrates the existing types of cooperation, the role of each entity and its competences. In addition, it highlights the key factors for successful collaborations and the major risks associated with them. Both literature sources and case studies are reviewed.

\section{Definition and Types}

The collaboration between the public and the private sectors are named in a number of different ways such as Public Private Partnerships (PPP), Private Finance Initiative (PFI), P3s, etc. They include a broad scope of organizational arrangements and they usually involve a series of distinct agreements [5].

According to the EU [6] Public Private Partnerships are "innovative financing solutions" in between traditionally procured government projects and fully privatized enterprises [5]. Figure 1 shows the different types of PPPs.

According to the World Bank [8], PPPs are medium/long term arrangement whereby the public and private sector act together to deliver services to the public. In this way, the two sectors share capital and skills as well as risks, responsibilities and benefits [9]. The AECOM consult team [4] elaborated Figure 2, which shows the main type of Public Private Partnerships in the transportation sector:

Through the various forms of PPPs the Government maintains the control over the strategic sectors, but benefits from the know-how and resources of the private sector [10]. Thanks to the delegation of daily works, Governments can focus on policy, planning and regulation [11]. Figure 3 shows the duties and competences of each part in every step of the project.

\section{Risks}

Investments in infrastructure have a high rate of risk for the private partner, since they usually are very expensive and have long payback periods [13]. In addition, changes in the political and regulatory framework threaten the project's success [14]. Grimsey and Lewis [15] detected the risks for an infrastructure project associated with design, building, managing, incomes, financing, extraordinary events, and environment. Private entities often ask Governments to protect them through extensive guarantees [13]. However, it is better to limit them; oth-

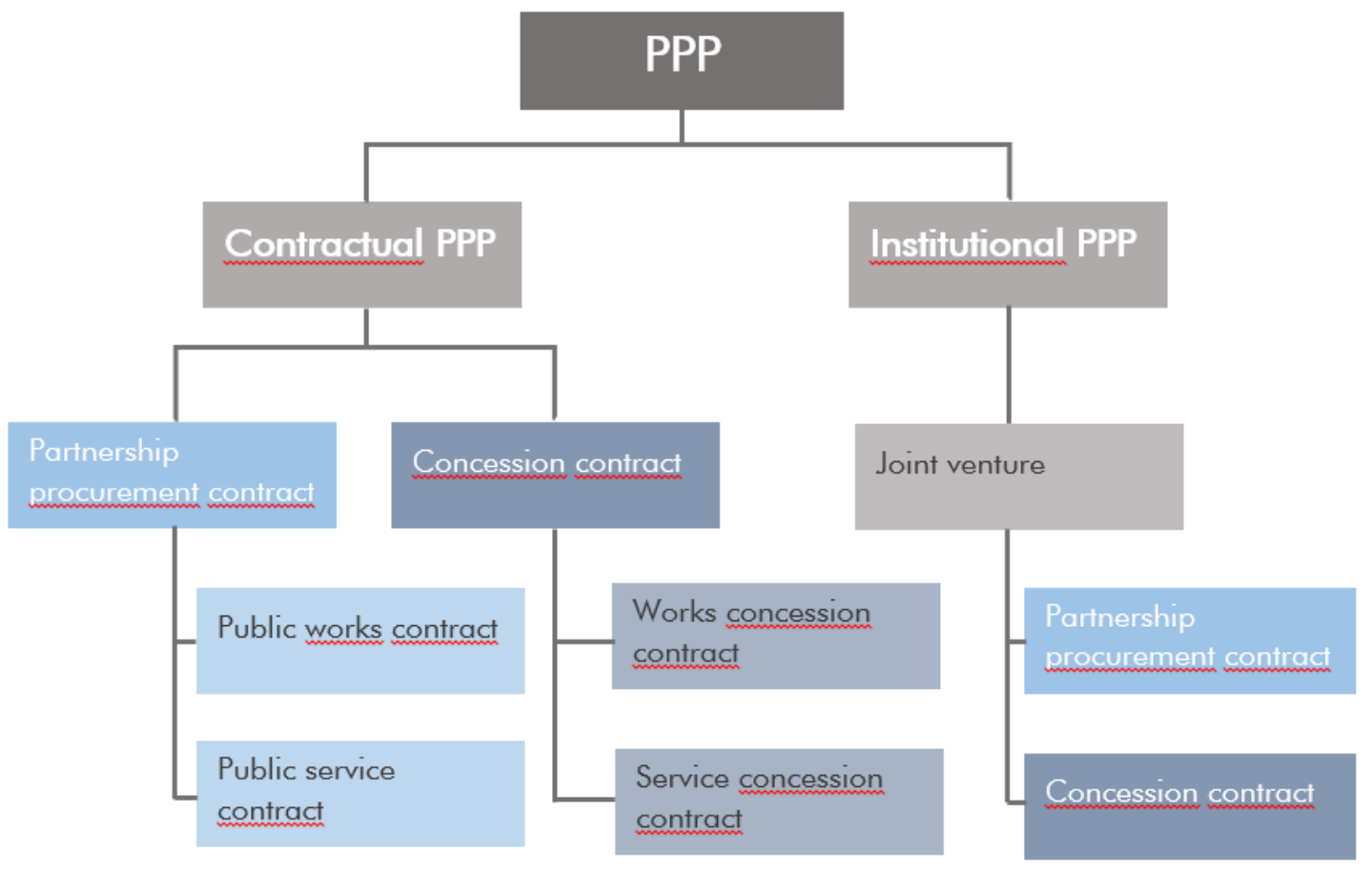

Figure 1. Types of public private partnerships [7]. 
- Asset Sale

- Full Service Long-Term Concession or Lease

- Multimodal Agreement

- JDA: Joint Development Agreement

- TOD: Transit-Oriented Development

- BOO: Build-Own-Operate

- BOOT: Build-Own-Operate-Transfer

- BTO: Build-Transfer-Operate

- BOT: Build-Operate-Transfer

- DBFO: Design-Build-Finance-Operate

- DBOM: Design-Build-Operate-Maintain

- DB-W: Design-Build with Warranty

- DB: Design-Build

- CM@Risk: Construction Manager at Risk

- Contract Maintenance

- Fee-Based Contract Services

Figure 2. PPPs in the transportation sector [4].

\begin{tabular}{|c|c|c|c|c|}
\hline Delineation & Public secto & ax effectiveness & In expenditure & Conclusion \\
\hline $\begin{array}{l}\text { - Study of market } \\
\text { trends } \\
\text { - Objectives setting } \\
\text { - Designation of } \\
\text { convenient projects } \\
\text { - Definition of legal } \\
\text { and regulative } \\
\text { frameworks } \\
\text { - Cost benefit analysis }\end{array}$ & $\begin{array}{l}\text { - Enhance packages } \\
\text { to attract potential } \\
\text { offers } \\
\text { - Supply data about } \\
\text { the project } \\
\text { - Recognize possible } \\
\text { candidates for the } \\
\text { bid }\end{array}$ & $\begin{array}{l}\text { - Procedure definition } \\
\text { - Preparation of } \\
\text { tender documents } \\
\text { - Development of } \\
\text { assessment criteria } \\
\text { - Valuation of bids } \\
\text { from private sector } \\
\text { - Interview bidding }\end{array}$ & $\begin{array}{l}\text { - Project worth } \\
\text { - Contractual } \\
\text { qualification } \\
\text { - Funding feasibility } \\
\text { - Negotiations with } \\
\text { bidders and } \\
\text { financiers } \\
\text { - Risk assessment }\end{array}$ & $\begin{array}{l}\text { - Documentation } \\
\text { drafting } \\
\text { - Syndication/ } \\
\text { underwriting } \\
\text { process } \\
\text { - Contract placement }\end{array}$ \\
\hline
\end{tabular}

Private sector: win the tender and reach the max return on equity

Delineation

- Funding models

- Market aspects

- Risk assessment

- Agreement definition

- Financing alternatives
Economic structure

- Responsibility distribution

- Financing plans

- Tax structuring

- Security structure

- Negotiation with public sector counter-party

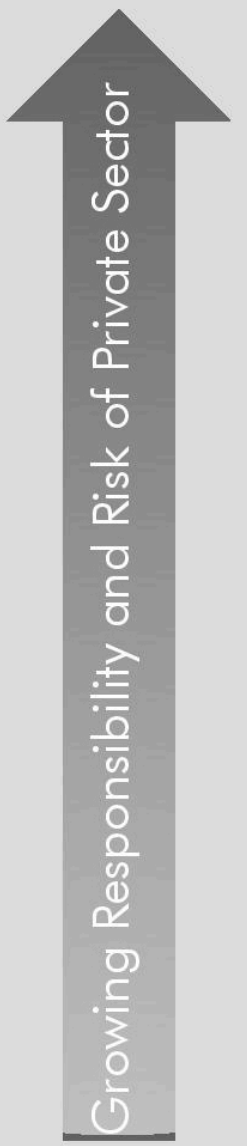


erwise, managers lose their interest in maximizing the project's profit [16]. Also Engel et al. [17] suggest that the Government does not bear construction risks because this would distort the bidding process, weaken the protection against "white elephants" (projects with negative net present value) and would postpone government obligations.

\section{Successful PPP}

Numerous bodies outline various factors for a successful Public Private Partnership. According to the PPPIRC [11], the main ones are the definition of long-term objectives, risk analysis and the outline of the national and international legal framework. The NCPPP [9] identifies seven key factors that lead to successful Partnerships: promotion of PPPs by recognized public figures, transparency and competitiveness, public agency specifically committed to PPPs, detailed business plan, clear revenue-stream, stakeholders engagement and designation of the right partner.

Li et al. [18] summarized the numerous factors identified by various authors. They confirmed the ones already mentioned. In addition to these, they also cited commitment of the parts involved, cost/benefit assessment, technical feasibility, definition of multi-benefit objectives, supportiveness of the legal framework, availability of the financial market, soundness of the political economy, stability of the macro-economic environment, social support, technology transfer, good governance and government guarantees.

\section{Case Studies}

Five case studies from Chile, Hungary, South Africa-Mozambique, United Kingdom and California have been considered. Figure 4 shows their locations.

Table 1 summarizes the main characteristics of the five transportation infrastructure projects examined.

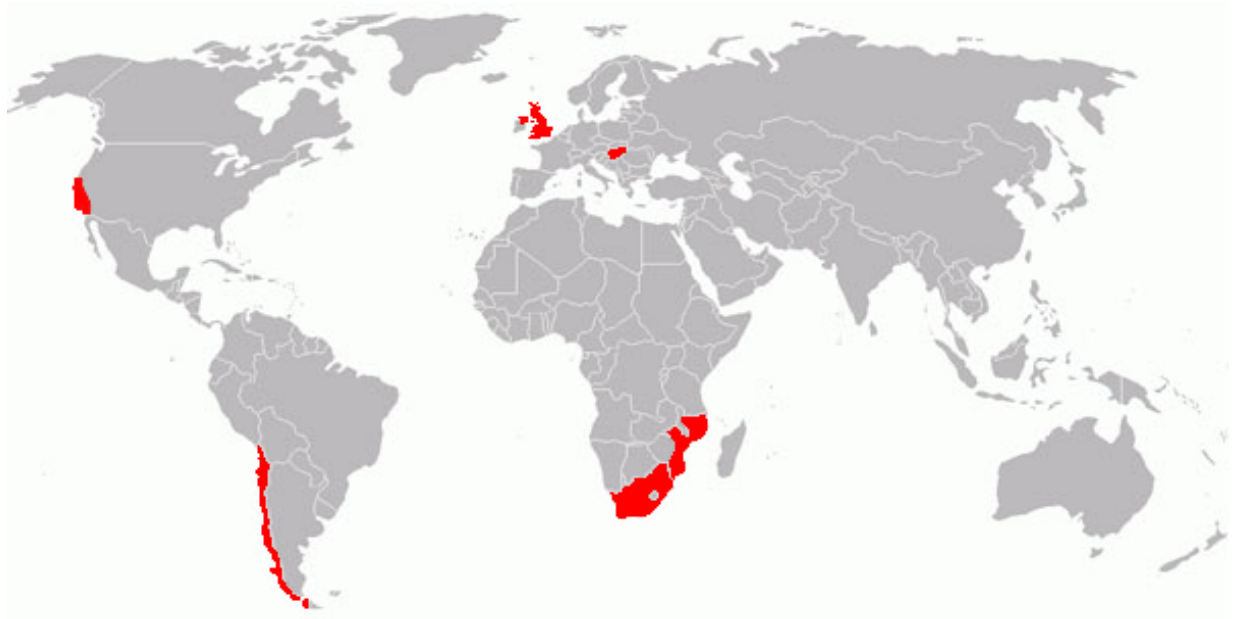

Figure 4. Location of projects examined [19].

Table 1. Case studies characteristics [4] [8] [20]-[26].

\begin{tabular}{|c|c|c|c|c|c|}
\hline Country & Chile & Hungary & South Africa-Mozambique & United Kingdom & California \\
\hline Project & Sistema Norte-Sur & M1-M15 & N4 toll road & M6 toll road & SR-125 \\
\hline Date (start-end) & 2000-2006 & 1994-1998 & 1997-2007 & 1992-2003 & 1991-2007 \\
\hline Concession duration & 30 years & 35 years & 30 years & 53 years & 35 years \\
\hline PPP model & $\mathrm{BOT}$ & DBFO & BOT & DBFO & DBFO \\
\hline Investment & US\$600 million & EU€280 million & $\begin{array}{c}\text { ZAR } 3 \text { billion } \\
\text { (=US\$660 million in 1996) }\end{array}$ & UK£900 million & UK£635 million \\
\hline Length & $61.2 \mathrm{~km}$ & $57 \mathrm{~km}$ & $630 \mathrm{~km}$ & $44 \mathrm{~km}$ & $9.5 \mathrm{~km}$ \\
\hline
\end{tabular}


The highway in Chile is the first case in the world where charges are inter-operable among four roads tendered to distinct concessionaires. The investor is supposed to remunerate its investment through tolls, but the Government subsidizes complementary projects and grants a minimum income equal to the sum of the $70 \%$ of the investment and the costs for management and maintenance. In addition, the Government has to compensate the concessionaire for the delays caused by local community opposition to the project [22].

The M1-M15 is the first toll motorway in project finance in Central Europe. Optimistic traffic forecasts request high toll rates. This causes unpopularity of tolls, which finally leads to the nationalization of the highway. The Government does not provide any initial financial contribution, but imposes restrictions on the construction of other competing roads and provides the land for the highway layout. However, revenue shortfalls and complains about the consequent high tolls force the Government to substitute the Concessionaire taking on the biggest amount of the debt. [23].

The N4 toll road is a successful example of cooperation between the neighbouring countries South Africa and Mozambique without government subsidies. Toll rates vary according to the heavy of vehicles and local economy. This means that toll rates increase differently in South Africa and Mozambique due the rate fluctuation between the national currencies [24].

The M6 toll road is the first toll road in UK, apart from bridges and tunnels. Since there were not government grants, financial benefits are not shared. This has been agreed upon because the private partner initially took all the risks. Even though the project was refinanced by the Public partner, this aspect was not revised. The M6 is another example of local opposition caused by the aversion to tolls and by environmental issues [25].

The SR-125 has been delayed by the absence of funds due to the strictness of the PPP financing model. Federal funds are not granted because tolls are supposed to be the main source of financing; however, a State loan covers the debt service costs since it is not considered a direct state funding. Another key issue of this project is the environmental assessment undertook by the private partner that lasts much longer than expected with consequent increased costs [26].

\section{Conclusions}

This paper shows the benefits for the public sector from partnerships with private entities in the deliverability of infrastructure. Thanks to the partnerships, risks have been shared; costs have been cut and the public sector benefits from private expertise and financial funds. In addition, competences are properly appointed to each entity so that the public sector has less duty and, consequently, more time for planning activities. Nevertheless, a tricky point is identified: the risk assumption. Indeed, the private sector is not willing to entirely accept the risk associated with infrastructure provision and ask for government grants. However, this kind of protection might reduce the advantages of the partnership and, as a consequence, it would be better to limit it. The N4 and the M6 prove that infrastructure can be fully provided by the private sector, but the other case studies suggest that this might be difficult and public incentives could eventually be necessary. Indeed, California paid the debit service costs, Chile funded additional projects and ensured a minimum gain, and the Hungary eventually took over even the complete control of the motorway. The challenges are to provide subsidies without compromising efficiency, and to find a forms of collaboration through which each partner is responsible for the aspects that match its structure and competencies. The Californian project, for example, suggests that the environmental assessment is more suitable for the Public partner as it should handle it easier than the private one.

It is recommendable to include local communities in the planning process as well, particularly in the very first strategic phases. In this way, a shared vision will be agreed upon and subsequent oppositions to the project may eventually be avoided. Indeed, both in the UK and in Chile local communities demonstrated against the projects. In particular, the Chilean case study shows that the lack of a well-conducted public consultation might lead to delays in the delivery of the project and, consequently, to higher costs.

\section{Acknowledgements}

Special thanks are due to Prof. Corrado Zoppi for his invaluable collaboration and precious advice that greatly enriched the research.

Deepest gratitude is due to Alex Barton Cáceres for his meticulous proofreading and for his constant support and encouragement during the paper editing. 


\section{References}

[1] CEC (Commission of the European Communities) (2009) Mobilising Private and Public Investment for Recovery and Long Term Structural Change: Developing Public Private Partnerships. Brussels (Belgium): Commission of the European Communities.

[2] Canning, D. and Fay, M. (1993) The Effects of Transportation Networks on Economic Growth, Columbia University: Department of Economics Discussion Paper.

[3] Milbourne, R., Otto, G. and Voss, G. (2003) Public Investment and Economic Growth. Applied Economics, 35, 527540. http://dx.doi.org/10.1080/0003684022000015883

[4] AECOM Consult Team (2007) Case Studies of Transportation Public-Private Partnerships around the World. s.n, Arlington.

[5] Moseley, M.M. (2012) What Is a Public-Private Partnership? [Sound Recording].

[6] EU (European Union) (2010) Developing Public Private Partnerships. http://europa.eu/legislation_summaries/employment_and_social_policy/eu2020/em0026_en.htm

[7] Ministry of Finance Republic of Latvia (2012) PPP Types/Forms. http://www.fm.gov.lv/en/s/ppp/about_ppp/ppp_types_forms/

[8] The World Bank (2014) Building Integrated Markets within the East African Community: EAC Opportunities in Public-Private Partnership Approaches to the Region’s Infrastructure Needs. World Bank Publications, Washington DC.

[9] NCPPP (The National Council for the Public-Private Partnership) (2014) 7 KEYS TO SUCCESS. http://www.ncppp.org/ppp-basics/7-keys/ Wright and Wright, W. (1906) Flying-Machine. US Patent No. 821393.

[10] OECD (2008) Regulatory Frameworks for Successful PPPs in MENA Countries: Emerging Good Practice. In: Making Reforms Succeed: Moving Forward with the MENA Investment Policy Agenda. s.l.: OECD Publishing, 263-292. http://dx.doi.org/10.1787/9789264052826-12-en

[11] PPPIRC (Public Private Partnership in Infrastructure Resource Centre) (2014) About Public-Private Partnerships. http://ppp.worldbank.org/public-private-partnership/overview

[12] PwC (2014) Governments \& Infrastructure. http://www.pwc.com/sg/en/industries/government-and-infrastructure.jhtml

[13] Irwin, T., Klein, M., Perry, G.E., Thobani, M. (1997) Dealing with Public Risk in Private Infrastructure. In: Dealing with Public Risk in Private Infrastructure: An Overview. The International Bank for Reconstruction and Development/ The World Bank, Washington DC, 1-18.

[14] Smith, W. (1997) Covering Political and Regulatory Risks: Issues and Options for Private Infrastructures Arrangements. In: Dealing with Public Risk in Private Infrastructure. The International Bank for Reconstruction and Development/The World Bank, Washington DC, 45-88.

[15] Grimsey, D. and Lewis, M.K. (2004) Public Private Partnerships the Worldwide Revolution in Infrastructure Provision and Project Finance. Edward Elgar Publishing Limited. Cheltenham.

[16] Irwin, T. (2007) Government Guarantees Allocating and Valuing Risk in Privately Financed Infrastructure Projects. The International Bank for Reconstruction and Development/The World Bank, Washington DC. http://dx.doi.org/10.1596/978-0-8213-6858-9

[17] Engel, E., Fisher, R. and Galetovic, A. (1997) Infrastructures Franchising and Government Guarantees. In: Dealing with Public Risk in Private Infrastructure. The International Bank for Reconstruction and Development/The World Bank, Washington DC, 89-108.

[18] Li, B., Akintoye, A., Edwards, P. J. and Hardcastle, C. (2005) Critical Success Factors for PPP/PFI Projects in the UK Construction Industry. Construction Management and Economics, 23, 459-471. http://dx.doi.org/10.1080/01446190500041537

[19] Author's Work. http://upload.wikimedia.org/wikipedia/commons/3/31/Taiga.png

[20] Griffin, M. (2014) M6 Toll 10 Years on: Success or Failure? http://www.birminghammail.co.uk/news/local-news/m6-toll-10-years--6458817

[21] CEE Bankwatch Network (2014) M1/M15 and M5 Motorways, Hungary. http://bankwatch.org/public-private-partnerships/case-studies/m1m15-and-m5-motorways-hungary

[22] PPIAF (Public Private Infrastructure Advisory Facility) (2009a) Urban Highway Concessions in Santiago, Chile. http://www.ppiaf.org/sites/ppiaf.org/files/documents/toolkits/highwaystoolkit/6/case_studies/chile.html

[23] PPIAF (Public Private Infrastructure Advisory Facility) (2009b) M1/M15 Motorway, Hungary. http://www.ppiaf.org/sites/ppiaf.org/files/documents/toolkits/highwaystoolkit/6/case_studies/hungary.html 
[24] PPIAF (Public Private Infrastructure Advisory Facility) (2009c) N4 Toll Road from South Africa to Mozambique. http://www.ppiaf.org/sites/ppiaf.org/files/documents/toolkits/highwaystoolkit/6/case_studies/safricamozambique.html

[25] PPIAF (Public Private Infrastructure Advisory Facility) (2009d) M6 Toll, United Kingdom. http://www.ppiaf.org/sites/ppiaf.org/files/documents/toolkits/highwaystoolkit/6/case_studies/uk.html

[26] PPIAF (Public Private Infrastructure Advisory Facility) (2009e) Country case study: United States. http://www.ppiaf.org/sites/ppiaf.org/files/documents/toolkits/highwaystoolkit/6/case_studies/us.html 